\title{
Investigations on Vinylene Carbonate. V. Immobilization of Alkaline Phosphatase onto LDPE Films Cografted with Vinylene Carbonate and $\mathrm{N}$-Vinyl- $\mathrm{N}$-methylacetamide
}

\author{
GUOHUA CHEN, ${ }^{*}$ LEEN VAN DER DOES, ${ }^{\dagger}$ and ADRIAAN BANTJES \\ Department of Chemical Technology, Biomaterials Section, University of Twente, \\ P.O. Box 217, 7500 AE Enschede, The Netherlands
}

\begin{abstract}
SYNOPSIS
Low-density polyethylene (LDPE) films cografted with vinylene carbonate (VCA) and $N$ vinyl- $N$-methylacetamide (VIMA) were studied as a matrix for the immobilization of the enzyme alkaline phosphatase (ALP) either by direct fixation or by inserting spacers. When water-soluble alkyldiamines such as diaminoethylene, diaminobutane, diethylenetriamine, and diaminohexane were used as spacers between the matrix and the enzyme, the surface concentration (SC) of the active ALP coupled on the matrix was increased, whereas the effect of the spacer on the $\mathrm{SC}$ was dependent on the length of the spacer. Bovine serum albumin (BSA) was preimmobilized onto the LDPE films to provide a better simulation of the biological environment for the enzyme, and the SC of ALP on the matrix was significantly increased by coupling ALP onto the BSA preimmobilized surfaces. Compared to native ALP, some physicochemical properties of ALP could be improved by the covalent immobilization. (c) 1993 John Wiley \& Sons, Inc.
\end{abstract}

\section{INTRODUCTION}

A large number of natural and synthetic polymers have been used as water-insoluble supports for the attachment of biological compounds, particularly enzymes, ${ }^{1-3}$ and several methods have been developed for the immobilization. Coupling of enzymes by ion binding or by physical adsorption can easily be carried out, but the enzymes immobilized by these methods tend to be released gradually from the supports. ${ }^{1,2}$ Therefore, the method based on covalent binding of enzymes onto matrices seems to be the most important because leakage of the enzyme can be avoided to a great extent. ${ }^{4-8}$

To be suitable for covalent immobilization of enzymes, in general, the supports should display the following properties: a hydrophilic nature, an ap-

* Present address: Department of Bioengineering, FL-20, University of Washington, Seattle, Washington 98195.

† To whom correspondence should be addressed.

Journal of Applied Polymer Science, Vol. 47, 25-36 (1993)

(C) 1993 John Wiley \& Sons, Inc.

CCC 0021-8995/93/010025-12 propriate concentration of chemically active groups (or groups suitable for activation), a high chemical and mechanical stability, resistance to biodegradation, and, last but not least, a nontoxic behavior. ${ }^{3}$ Additionally, the covalent binding of enzymes onto water-insoluble supports must be carried out under mild conditions to avoid inactivation of the enzymes. $^{1-3,9}$

The application of graft copolymers as supports for the immobilization of biomolecules has been reported by several authors. ${ }^{10-17}$ Graft copolymers could offer several advantages as supports, since they can be prepared with varying hydrophilic and mechanical properties and, in addition, it will be possible to influence the microenvironment for the biomolecules on the support.

Cyclic carbonate (CCA) groups are known to react with amino groups in proteins under mild conditions, resulting in stable urethane structures. ${ }^{18}$ Cellulose derivatives ${ }^{6,18,19}$ in which CCA groups had been introduced by reaction with ethyl chloroformate ${ }^{20}$ and copolymers of vinylene carbonate (VCA) $)^{21-23}$ have been reported as matrices for immobilization of enzymes, antigens, etc. 
In a previous paper, ${ }^{24}$ we reported the cografting of VCA and $N$-vinyl- $N$-methylacetamide (VIMA) onto low-density polyethylene (LDPE) films. Grafting had resulted in an increase of the hydrophilicity of the films, whereas due to a positive synergistic effect of VIMA, a reasonable amount of VCA groups had been grafted.

Because reports from the literature indicate that, using CCA groups, biologically active compounds can be immobilized under mild conditions without activation, the applicability of the graft copolymers for the immobilization of enzymes was studied.

Although these matrices might be used to bind different sorts of biomolecules or ligands, a selection was made. This paper deals with the immobilization of the enzyme alkaline phosphatase (ALP) onto VCA-VIMA-grafted LDPE films. To study the effect of a spacer ${ }^{25-27}$ on the immobilization of ALP, water-soluble alkyldiamines with various chain lengths were used. Attempts were made to increase the surface concentration of active ALP fixed on the support by coupling ALP onto bovine serum albumin (BSA )-preimmobilized surfaces to provide a better simulation of the biological environment for the enzyme. ${ }^{28,29}$ In addition, the dependence of the activity of the immobilized ALP under several conditions was studied.

\section{EXPERIMENTAL}

\section{Materials}

$N$-Vinyl- $N$-methylacetamide (VIMA, Janssen Chimica, Beerse, Belgium) was distilled under reduced pressure before use; vinylene carbonate (VCA) was prepared as described in Ref. 30. Low-density polyethylene film (LDPE, $0.05 \mathrm{~mm}$ thick) was a product of Talas (Ommen, The Netherlands). Alkaline phosphatase (ALP, E.C.3.1.3.1 from Bovine Intestinal Mucosa, Type 1-S), bovine serum albumin (BSA), and $p$-nitrophenyl phosphate disodium salt $(p N P P)$ were products from Sigma Chemical Co. (St. Louis, MO). All other reagents used were of analytical grade.

\section{Characteristics of VCA-VIMA Grafted LDPE Films}

LDPE films grafted with mixtures of VCA and VIMA were prepared according to the procedure described in Ref. 24. As a matrix for the coupling of enzymes, films with a rather hydrophilic surface and a sufficient amount of functionally reactive groups are required. The films used in this study for the coupling process had a total grafting yield of $13.2 \%$
( $w / w)$, a VCA/VIMA molar ratio in the graft copolymer of $23 / 77$, and a receding contact angle of $56{ }^{\circ}{ }^{24}$ Films were cut into $2.2 \mathrm{~cm}$-diameter discs for the coupling experiments, and before the reaction, the discs were preswelled in $0.05 M$ Tris- $\mathrm{HCl}$ buffer at room temperature for $24 \mathrm{~h}$.

\section{FTIR Measurements}

IR measurements of the grafted polyethylene films as well as of films after reactions with alkyldiamines were carried out using a Bio-Rad FTS-60 FTIR spectrophotometer. The operating parameters were the following: resolution $2 \mathrm{~cm}^{-1}$, scanning number 64 , and absorbance measurements. Attenuated total reflectance (ATR) spectra for the surface analysis were recorded using a KRS-5 optical prism internal reflection element with a face cut of $45^{\circ}$.

\section{Contact-angle Measurements}

Surfaces of grafted films and of films after modifications with alkyldiamines or with BSA were also characterized by contact-angle measurements (receding) using the captive bubble method.$^{31}$ The films were cut into small pieces (at least six), fixed on a plastic matrix, and immersed in double-distilled water for $24 \mathrm{~h}$ before the measurements.

\section{Immobilization of ALP}

ALP $\left(\mathrm{NH}_{2}-(B)\right.$ was covalently immobilized onto VCA-VIMA-grafted LDPE films (GVV) in several steps, by direct coupling [Scheme 1(a)], or by indirect coupling with different spacers [Scheme 1(b), Scheme 2(a) - (d)].

A typical immobilization experiment without a spacer was carried out as follows: The grafted film ( $2.2 \mathrm{~cm}$ diameter) was placed in $3 \mathrm{~mL}$ ALP solution $(2.0 \mathrm{mg} / \mathrm{mL} \mathrm{ALP})$ in $0.05 M$ Tris-HCl buffer at $\mathrm{pH}$ 8 and shaken at $4^{\circ} \mathrm{C}$ for $16 \mathrm{~h}$ [Scheme 1(a)]. The film was then washed several times with the same buffer to remove unreacted ALP and stored in the buffer at $4^{\circ} \mathrm{C}$. The residual CCA groups were blocked with ethanolamine (EA). ${ }^{9}$

The immobilization of ALP onto the grafted films using spacers with alkyl chains was performed via two steps [Scheme 1(b)]: i.e., a reaction of the alkyldiamines (DA) with the CCA groups on the grafted films followed by a glutaraldehyde (GA) treatment. ${ }^{4,32}$ In this study, the water-soluble alkyldiamines such as diaminoethylene (DAE), diaminobutane (DAB), diethylenetriamine (DETA), and diaminohexane (DAH) were used to act as a spacer 


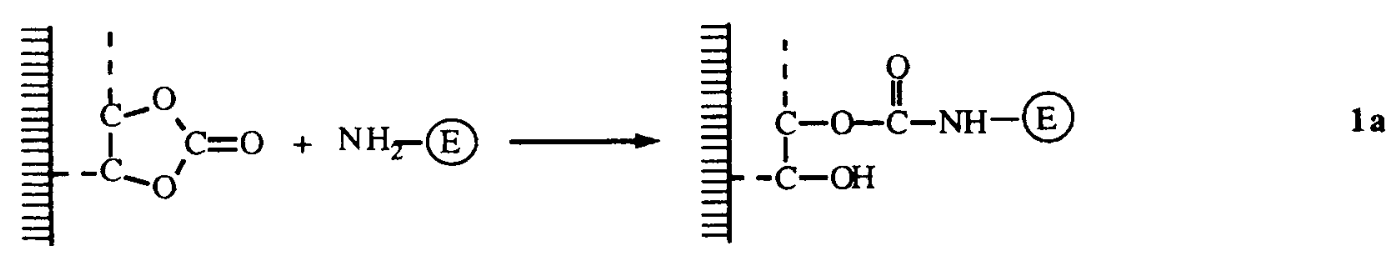

GVV

GVV-E
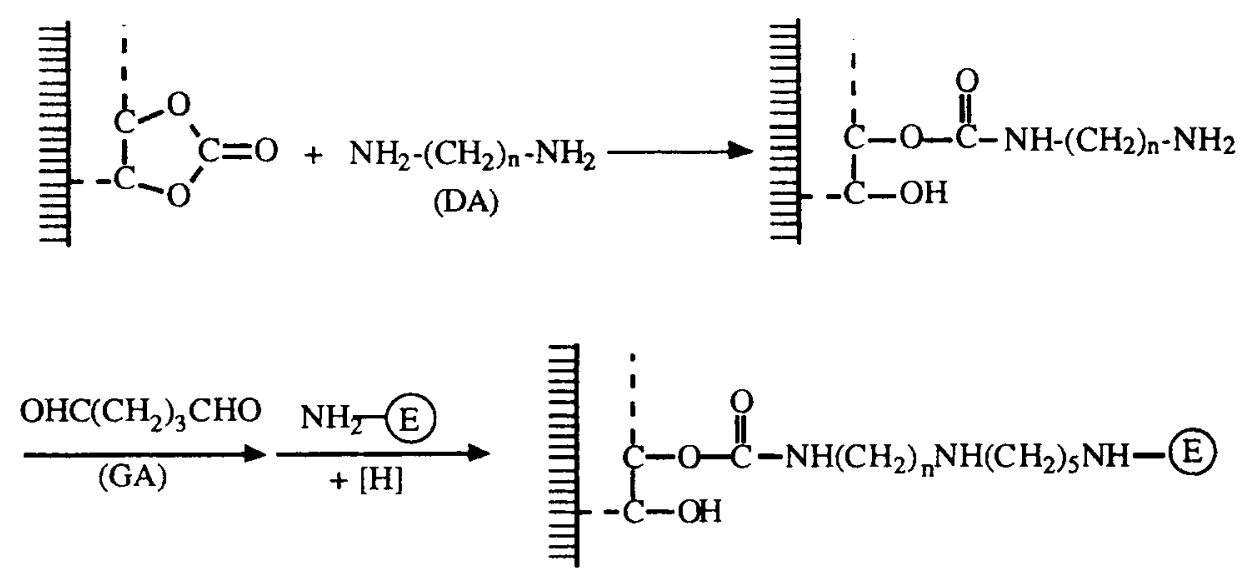

1 b

\section{GVV·DA-E}

Scheme 1 Coupling of ALP $\left(\mathrm{NH}_{2}-(\right.$ C) $)$ directly or through alkyl spacers onto VCAVIMA-grafted LDPE films.

for coupling ALP to the support. The reactions of the alkyldiamines with the grafted films were carried out by shaking the films $(2.2 \mathrm{~cm}$ diameter $)$ in 10 $\mathrm{mL}$ aqueous diamine solution $(10 \% \mathrm{w} / \mathrm{v})$ at room temperature for $2 \mathrm{~h}$. The reacted films were washed with a large amount of distilled water to free the unreacted diamines. The products were analyzed by FTIR to determine if all the CCA groups on the surface of the films had reacted. The free amino groups reacted in a second reaction with $\mathrm{GA}$, which was done by immersing the modified films in $10 \mathrm{~mL}$ of $5 \%(\mathrm{v} / \mathrm{v})$ aqueous GA solution. After $30 \mathrm{~min}$ shaking at room temperature, the films were removed and washed several times with distilled water to eliminate unreacted GA (FTIR measurements illustrated that the reaction proceeded completely and no free amino groups could be found on the surface). The immobilization of ALP on the GA-activated films was carried out as in the case of direct coupling. After reaction, the films were treated for $3 \mathrm{~min}$ at $0^{\circ} \mathrm{C}$ with $0.1 M \mathrm{NaBH}_{4}$ to stabilize the linkage of the enzyme to the support and to reduce the unreacted carbonyl groups of the bifunctional agent GA. ${ }^{4}$
In some experiments, before coupling of ALP, BSA was preimmobilized to create a better biological environment for the enzyme [Scheme 2(a)(d) ].$^{28,29}$ The grafted films or the films after activation with GA were placed in $5 \mathrm{~mL}$ BSA solution $(3.0 \mathrm{mg} / \mathrm{mL})$ in $0.05 \mathrm{M}$ Tris-HCl buffer at $\mathrm{pH} 8$ and shaken at room temperature for $24 \mathrm{~h}$. The unreacted CCA groups or aldehyde group were blocked with $\mathrm{EA}^{9}$ or reduced with $\mathrm{NaBH}_{4}$, respectively. The films were then refluxed for $30 \mathrm{~min}$ to denature the coupled BSA. ${ }^{28}$ Immobilization of ALP on the albuminated films was carried out as shown in Scheme 1(b).

\section{Activity Assays on ALP}

The activity of the native and the immobilized ALP was determined spectrophotometrically (UVIKON 930 spectrophotometer) using $p$ NPP as the substrate ( $p$ NPP concentration, $0.45 \mathrm{mM}$ ) in $0.1 M$ glycine buffer at $\mathrm{pH} 9.40$ with $1 \mathrm{mM} \mathrm{MgCl} 2$ and $\mathrm{ZnCl}_{2}$, at $25^{\circ} \mathrm{C}$ according to Bessey et al..$^{33}$ and Con- 

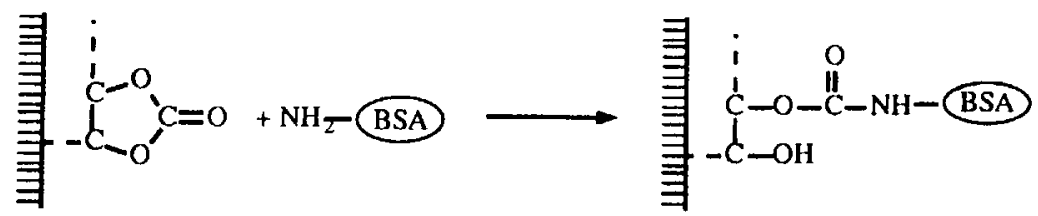

I

$$
\text { I }+\mathrm{NH}_{2} \text { (E) } \frac{\mathrm{GA}}{+[\mathrm{H}]}
$$

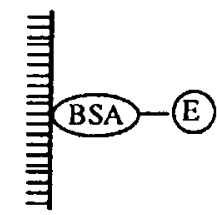

$2 \mathbf{a}$

GVV-A-E

I $\stackrel{\mathrm{GA}}{\longrightarrow} \frac{\mathrm{NH}_{2}\left(\mathrm{CH}_{2}\right)_{6} \mathrm{NH}_{2}}{(\mathrm{DAH})} \frac{(1) \mathrm{GA}}{(2) \mathrm{NH}_{2}-(\mathrm{E})}$ (3) $+[\mathrm{H}]$

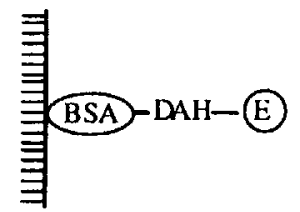

$\mathbf{2 b}$

GVV-A-DAH-E

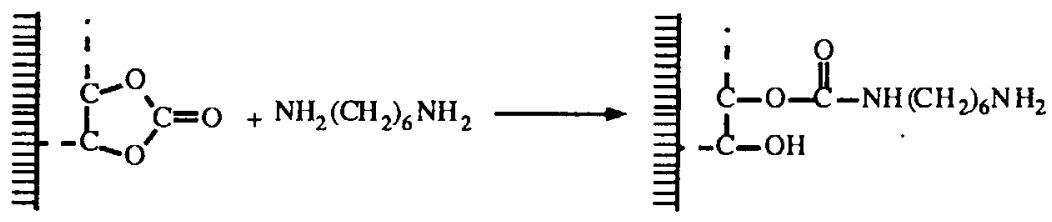

II

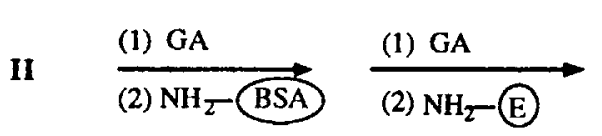

(3) $+[\mathrm{H}]$

(3) $+[\mathrm{H}]$
$2 \mathrm{c}$

2d lon and Walt. ${ }^{34}$ The activity of ALP was calculated as follows ${ }^{34}$ :

Activity (unit $/ \mathrm{mg}$ or $\mathrm{cm}^{2}$ ) $=\frac{V}{\epsilon \cdot l \cdot s} \times \Delta E$ where $V$ is the final volume of the assay solution; $\epsilon$, the molar extinction coefficient $\left[\epsilon_{405 \mathrm{~nm}}=18.5\left(\mathrm{~cm}^{2} /\right.\right.$ $\mu \mathrm{mol}$ ) for $p$-nitrophenol $\left.{ }^{34}\right]$; $l$, the cuvette length $(1 \mathrm{~cm}) ; s$, the sample size of the enzyme used for 
the assay $-\mathrm{mg}$ for the native ALP and $\mathrm{cm}^{2}$ for the films with immobilized ALP; and $\Delta E$, the increment of the absorbance at $405 \mathrm{~nm}$ per minute. The surface concentration of active enzyme bound onto the films was calculated as

Active ALP immobilized ( $\mathrm{ng} / \mathrm{cm}^{2}$ film)

$$
=\frac{\text { Activity } / \mathrm{cm}^{2} \text { film }}{\text { Activity } / \mathrm{ng} \text { native ALP }}
$$

\section{Effect of pH on Activity of Native and Immobilized ALP}

The activity of native and immobilized ALP at different $\mathrm{pH}$ values (ranging from 8.5 to 10.6 ) was measured at a temperature of $25^{\circ} \mathrm{C}$ with a $p$ NPP concentration of $0.45 \mathrm{mM}$ in $0.1 \mathrm{M}$ glycine buffer with $1 \mathrm{~m} M \mathrm{MgCl}_{2}$ and $\mathrm{ZnCl}_{2}$.

\section{Thermal Stability of Native and Immobilized ALP}

Native ALP and films with immobilized ALP were incubated in $0.05 \mathrm{M}$ glycine buffer, $\mathrm{pH} 9$, at $37^{\circ} \mathrm{C}$ for different times. Samples were taken, kept at $25^{\circ} \mathrm{C}$ for 5-10 min, and the activity determined as described earlier. The first-order inactivation rate constant $k_{i}$ was evaluated by the equation

$$
\ln A=\ln A_{0}-k_{i} t
$$

where $A_{0}$ is the initial activity and $A$ is the activity after heat treatment for $t$ min. ${ }^{35}$

\section{Determination of Michaelis Constants}

The Michaelis-Menten constant $K_{m}$ of native and immobilized ALP was evaluated using $p$ NPP solutions (ranging from 1.25 to $45 \times 10^{-2} \mathrm{mM}$ ) in $0.1 M$ glycine buffer at $\mathrm{pH} 9.4$, with $1 \mathrm{~m} M \mathrm{MgCl}_{2}$ and $\mathrm{ZnCl}_{2}$ at $25^{\circ} \mathrm{C}$ on the basis of the Lineweaver-Burk plot:

$$
\frac{1}{\nu(\Delta[S])}=\frac{K_{m}}{V_{\max }} \cdot \frac{1}{[S]}+\frac{1}{V_{\max }}
$$

where $\nu$ is the reaction rate, i.e., the change of the concentration of the substrate with time $(\Delta S) ;[S]$, the concentration of the substrate; $V_{\max }$, the maximum reaction rate; and $K_{m}$, the Michaelis-Menten constant.

\section{Reusability of Immobilized ALP}

The activity of immobilized ALP was determined initially. The film was washed thoroughly with $0.05 M$ glycine buffer at $\mathrm{pH} 9$ and was used for the next activity measurement. The process was repeated 11 times and the activity was determined in each case.

\section{Storage Stability of Immobilized ALP}

The immobilized ALP was stored in $0.05 M$ Tris$\mathrm{HCl}$ buffer, $\mathrm{pH} 8$, at $4^{\circ} \mathrm{C}$, and the activity was de-

\begin{tabular}{|c|c|c|c|c|}
\hline Sample & $\begin{array}{c}{[E]} \\
(\mathrm{mg} / \mathrm{mL})\end{array}$ & $\mathrm{pH}$ & $\begin{array}{c}\text { Reaction Time } \\
\text { (h) }\end{array}$ & $\begin{array}{l}\text { Active Enzyme } \\
\text { Immobilized }^{c} \\
\text { (ng/cm }{ }^{2} \text { film) }\end{array}$ \\
\hline GVV-E 1 & 1.0 & 8.0 & 16 & $2.0 \pm 0.1$ \\
\hline GVV-E 2 & 2.0 & 8.0 & 16 & $2.3 \pm 0.1$ \\
\hline GVV-E 3 & 3.0 & 8.0 & 16 & $2.5 \pm 0.1$ \\
\hline GVV-E 4 & 4.0 & 8.0 & 16 & $2.8 \pm 0.2$ \\
\hline GVV-E 5 & 5.0 & 8.0 & 16 & $3.1 \pm 0.2$ \\
\hline GVV-E 6 & 3.0 & 8.0 & 4 & $1.8 \pm 0.1$ \\
\hline GVV-E 7 & 3.0 & 8.0 & 8 & $2.2 \pm 0.1$ \\
\hline GVV-E 8 & 3.0 & 8.0 & 24 & $2.9 \pm 0.2$ \\
\hline GVV-E 9 & 3.0 & 7.0 & 16 & $1.9 \pm 0.1$ \\
\hline GVV-E 10 & 3.0 & 7.5 & 16 & $2.1 \pm 0.1$ \\
\hline GVV-E 11 & 3.0 & 8.5 & 16 & $1.9 \pm 0.1$ \\
\hline GVV-E 12 & 3.0 & 9.0 & 16 & $1.6 \pm 0.1$ \\
\hline
\end{tabular}
termined as a function of time.

Table I Results of Immobilization of ALP onto VCA-VIMA-grafted LDPE Films

\footnotetext{
a Immobilization was performed at $4^{\circ} \mathrm{C}$, with $3 \mathrm{~mL}$ ALP solution in $0.05 \mathrm{M}$ Tris-HCl buffer (pH 7.0-8.5) and glycine buffer (pH 9).

${ }^{b}$ GVV stands for the grafted LDPE films with VCA and VIMA; E stands for the enzyme (ALP).

' Calculated based on eq. (2); the activity was measured in $0.1 M$ glycine buffer with $1 \mathrm{mM} \mathrm{MgCl}_{2}$ and $\mathrm{ZnCl}_{2}, \mathrm{pH} \mathrm{9.4,} \mathrm{at} 25^{\circ} \mathrm{C}$; the activity of native ALP was $4.85 \mathrm{U} / \mathrm{mg}$.
} 


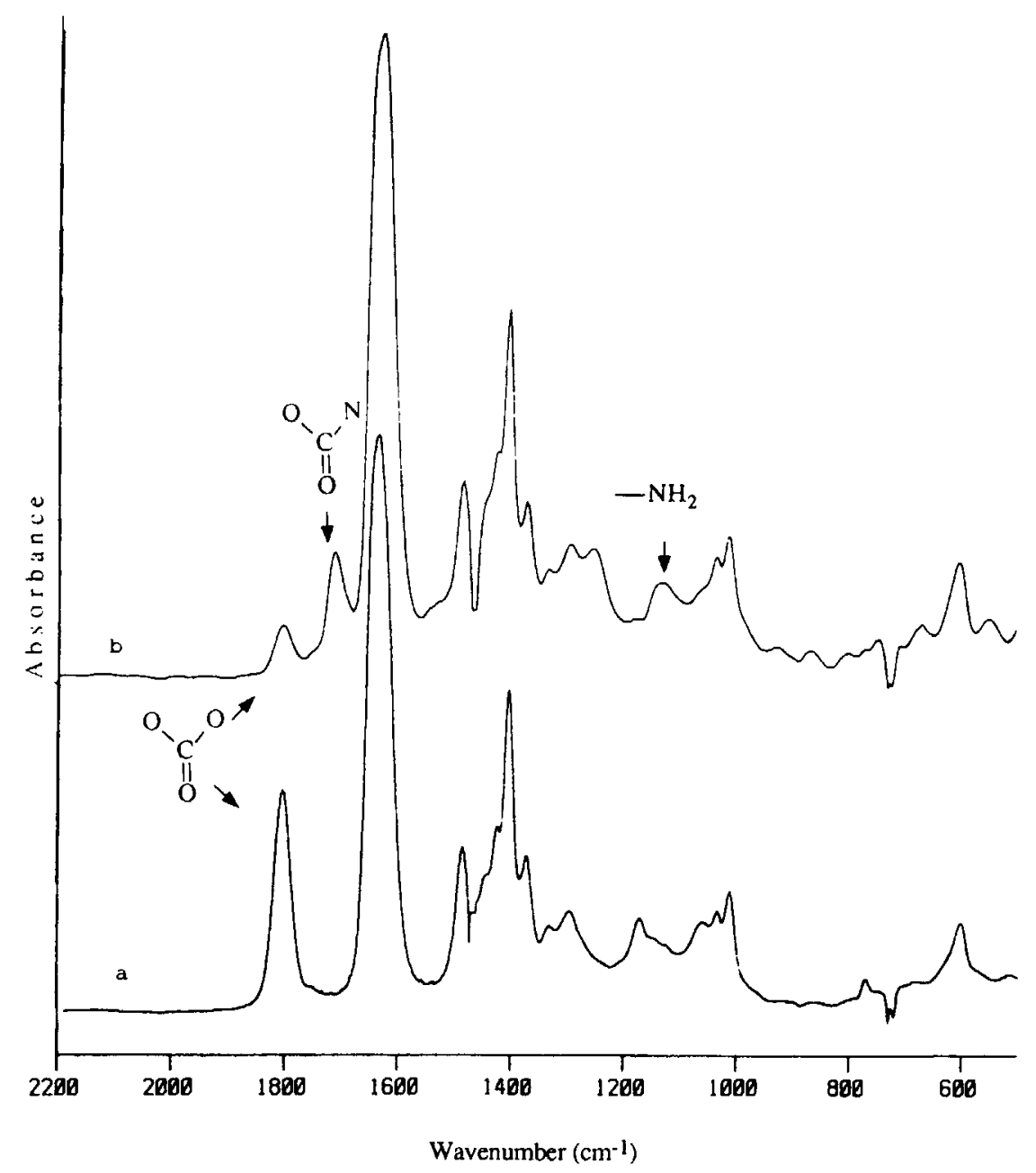

Figure 1 FTIR spectra of (a) a VCA-VIMA-grafted LDPE film; (b) the film after reaction with DAH.

\section{RESULTS AND DISCUSSION}

\section{Direct Coupling of ALP onto VCA-VIMA Grafted LDPE Films}

Covalent coupling of alkaline phosphatase (ALP) directly onto VCA-VIMA-grafted LDPE films was carried out by reaction of the cyclic carbonate groups in the graft copolymers with the amino groups in the enzyme, as shown in Scheme 1(a). The results obtained under various conditions are indicated in Table I. It can be seen that coupling of ALP had occurred onto the grafted LDPE films. The relatively low surface concentration of active ALP bound onto the films found for the direct coupling as shown in Table I might be due to the hydrophobic carbonate groups on the hydrophobic support (LDPE film), which would reduce the accessibility of the enzyme to the matrix and also cause a distortion of the enzyme as has been suggested by Abdel-Hay et al. ${ }^{36}$ for the immobilization of enzymes onto acrylic acidgrafted polyethylene matrices. Because of the small amounts of enzyme bound onto the films, the weight percentage of ALP coupled to the support could not be determined. However, this lack did not preclude a study on the effect of coupling conditions on the surface concentration of the active enzyme bound onto the support.

Table I shows that the surface concentration of the bound active ALP rose with increasing ALP concentration and with increasing reaction time. A similar effect was also reported by Hayashi and Ikada for the immobilization of lipoprotein lipase (LPL) onto polyacrolein (PAA) microspheres ${ }^{25}$ and by Emi et al. for the immobilization of papain and chymotrypsin onto copoly(ethylene/acrylic acid) 
Table II Results of immobilization of ALP onto VCA-VIMA-grafted LDPE films with Alkyl Chains as Spacers ${ }^{a}$

\begin{tabular}{|c|c|c|c|c|}
\hline Sample & Spacer & $\begin{array}{l}\text { Atoms } \\
\text { (n) }\end{array}$ & $\begin{array}{c}\text { Contact Angle } \\
\left({ }^{\circ}\right)\end{array}$ & $\begin{array}{l}\text { Active Enzymes } \\
\text { Immobilized }^{c} \\
\left(\mathrm{ng} / \mathrm{cm}^{2} \text { film }\right)\end{array}$ \\
\hline GVV-E & No & 0 & $56 \pm 3$ & 2.5 \\
\hline GVV-DAE-E & Diaminoethylene & 2 & $43 \pm 3$ & 3.1 \\
\hline GVV-DAB-E & Diaminobutane & 4 & $44 \pm 2$ & 4.5 \\
\hline GVV-DETA-E & Diethylenetriamine & 5 & $42 \pm 3$ & 5.4 \\
\hline GVV-DAH-E & Diaminohexane & 6 & $44 \pm 3$ & 8.1 \\
\hline
\end{tabular}

${ }^{a}$ Immobilization conditions: enzyme solution $3.0 \mathrm{~mL}$ in $0.05 \mathrm{M}$ Tris- $\mathrm{HCl}$ buffer, $\mathrm{pH}$ 8; enzyme concentration $3.0 \mathrm{mg} / \mathrm{mL}$; temperature $4^{\circ} \mathrm{C}$; reaction time $16 \mathrm{~h}$.

${ }^{b}$ Contact angle of films after reaction with alkyldiamines (except sample GVV-E) but before GA activation for coupling with ALP.

${ }^{\mathrm{c}}$ As indicated in Table I.

fiber. ${ }^{26}$ They found that the surface concentration of enzymes coupled on the matrices increased with increasing reaction time and increasing enzyme concentration, whereas the relative activity of the immobilized enzymes increased with the surface concentration of enzymes coupled onto the matrices. These results were explained in terms of structure deformation, ${ }^{25,26}$ i.e., the structure of the enzyme molecule immobilized by covalent fixation should undergo strong deformation, especially in the lower surface concentration region, being apt to decrease the relative activity with decreasing surface concentration. $^{26}$

In addition, as shown in Table $\mathrm{I}$, the $\mathrm{pH}$ of the reaction medium affected the immobilization of ALP onto the LDPE films; the best result was obtained at $\mathrm{pH}$ 8. (In the immobilization of ALP onto hydrogel beads of PVCA, a similar effect of the $\mathrm{pH}$ was found, although the optimal $\mathrm{pH}$ value was different $^{37}$.) Zemanova et al. investigated the coupling reaction of various proteins onto series of epoxide-containing matrices as a function of $\mathrm{pH}$ of the reaction mixture and found that the optimal $\mathrm{pH}$ for coupling was considerably affected by both the nature of the coupled protein and the nature of the solid matrix. ${ }^{8}$

\section{Effect of Spacers on the Immobilization of ALP onto VCA-VIMA-grafted LDPE Films}

It has been reported that the interposing of spacer arms, especially hydrophilic spacers, ${ }^{38}$ between the

Table III Immobilization of ALP onto VCA-VIMA-grafted LDPE Films with DAH as a Spacer

\begin{tabular}{|c|c|c|c|c|}
\hline Sample & $\begin{array}{c}{[E]} \\
(\mathrm{mg} / \mathrm{mL})\end{array}$ & $\mathrm{pH}$ & Reaction Time (h) & $\begin{array}{l}\text { Active Enzyme } \\
\text { Immobilized }^{\mathrm{b}} \\
\text { (ng/cm² film) }\end{array}$ \\
\hline GVV-DAH-E 1 & 1.0 & 8.0 & 16 & 8.3 \\
\hline GVV-DAH-E 2 & 2.0 & 8.0 & 16 & 8.6 \\
\hline GVV-DAH-E 3 & 3.0 & 8.0 & 16 & 8.1 \\
\hline GVV-DAH-E 4 & 4.0 & 8.0 & 16 & 6.4 \\
\hline GVV-DAH-E 5 & 5.0 & 8.0 & 16 & 5.0 \\
\hline GVV-DAH-E 6 & 3.0 & 8.0 & 4 & 6.1 \\
\hline GVV-DAH-E 7 & 3.0 & 8.0 & 8 & 7.0 \\
\hline GVV-DAH-E 8 & 3.0 & 8.0 & 24 & 7.6 \\
\hline GVV-DAH-E 9 & 3.0 & 7.0 & 16 & 7.0 \\
\hline GVV-DAH-E 10 & 3.0 & 7.5 & 16 & 8.3 \\
\hline GVV-DAH-E 11 & 3.0 & 8.5 & 16 & 6.1 \\
\hline GVV-DAH-E 12 & 3.0 & 9.0 & 16 & 5.0 \\
\hline
\end{tabular}

Immobilization conditions: see Table I.

${ }^{b}$ As indicated in Table I. 
Table IV Results of Immobilization of ALP onto VCA-VIMA-grafted LDPE Films through a BSA Spacer ${ }^{a}$

\begin{tabular}{llccc}
\hline & & & & \\
Contact \\
Angle \\
Expt.
\end{tabular}

support and the enzyme could reduce the steric interference and the distortion on the enzyme on binding, leading to a low loss of activity. ${ }^{25-28}$ In an attempt to bind more active ALP onto the support, immobilization of ALP was investigated by inserting various alkyl spacers. Films were reacted with an excess of alkyldiamines to introduce free amino groups onto the surface, and after activation with GA, ALP was immobilized as shown in Scheme 1(b).

The films before and after reaction with the alkyldiamines were characterized by FTIR measurements. Figure 1 shows a spectrum of a VCA-VIMAgrafted LDPE film (a) and a spectrum of the film after reaction with diaminohexane (DAH) (b). After reaction with $\mathrm{DAH}$, the absorbance of the cyclic carbonate groups at $1800 \mathrm{~cm}^{-1}$ was diminished and the absorbance of carbamate groups at ca. $1750 \mathrm{~cm}^{-1}$ and of primary amino groups at $1180 \mathrm{~cm}^{-1}$ appeared. However, the absorbance of the cyclic carbonate groups at $1800 \mathrm{~cm}^{-1}$ was not found by ATR-FTIR measurement, which probably indicates that the reaction of the carbonate groups on the surface was almost complete, whereas the absorbance of the carbonate groups as shown in Figure 1(b) originates from carbonate groups in the bulk of the film. VCA is a rather hydrophobic unit and its presence in the graft copolymers will reduce the hydrophilicity; however, after reaction with compounds containing amino groups, especially water-soluble ones such as the alkyldiamines used in this study, the rather hydrophilic $\beta$-hydroxyvinyl- $N$-alkylcarbamate groups ${ }^{39}$ will be formed, leading to a more hydrophilic surface on the grafted films.

The results of the immobilization of ALP onto VCA-VIMA-grafted LDPE films using alkyl chains as spacers are given in Table II. They show that by insertion of "spacer arms" between support and enzyme the surface concentration of active ALP coupled onto the films indeed increases and becomes higher with increasing spacer length. This effect might be due to a reduction of steric hindrance for the enzyme to approach the support during the binding process by the spacer, ${ }^{25-28}$ as well as to an improvement of the surface hydrophilicity of the films as indicated by the decrease of the contact angle, which would render the support more compatible with the enzyme ${ }^{38}$ and make the microenvironment around the enzymes more "comfortable." 40 The extent of coupling as well as the enzyme activity will depend on the hydrophilicity of the support and the accessibility of the enzyme. ${ }^{38}$ From Table II it can be seen that with a nearly constant contact angle the activity increased with increasing spacer length, indicating the marked influence of the spacer.

Because the increase of the surface concentration of immobilized active ALP was most pronounced by using DAH as a spacer, coupling with this spacer was studied in more detail (Table III). The effect of the ALP concentration on the surface concentration of active ALP coupled onto the support was found to be contrary to the influence by direct fixation (Table I). This might be due to the higher mobility of the GA coupling sites on the immobilized spacer toward ALP molecules as well as the improvement of the hydrophilicity (contact angle $44^{\circ}$ ). However, with increasing enzyme concentration, the probability for a multiple coupling of the enzyme onto the support could also be raised, leading to a decrease of the relative activity for the coupled enzyme. ${ }^{17,41}$ In addition, a longer coupling time might lead to an increase of the surface concentration of active ALP coupled onto the support, but the results 

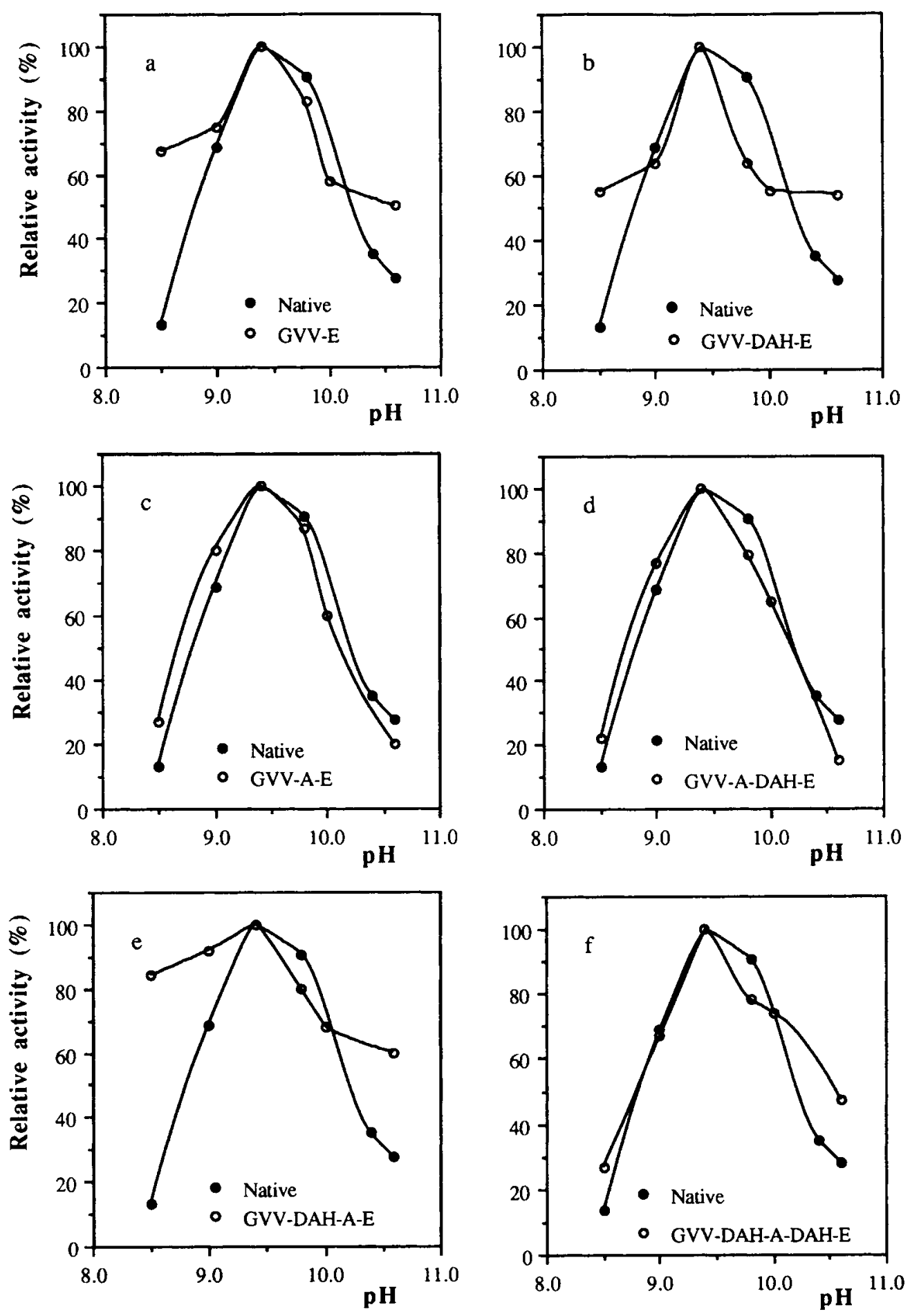

Figure 2 Effect of $\mathrm{pH}$ of the reaction medium on the activity of the immobilized ALP $\left(25^{\circ} \mathrm{C}\right)$.

show that the coupling time had only a small effect. The $\mathrm{pH}$ for a maximal coupling was found at $\mathrm{pH}$ 7.5 , slightly different from the value for direct fixation.
Coupling to Bovine Serum Albuminated Surface

Coupling of BSA onto the VCA-VIMA grafted LDPE films, followed by immobilization of ALP, 


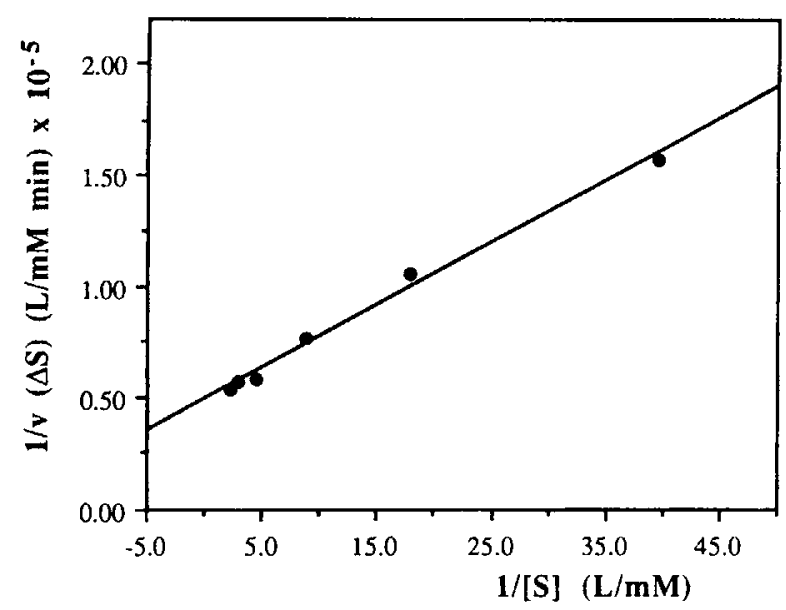

Figure 3 Lineweaver-Burk plot for native ALP.

resulted in a surface concentration of active enzyme bound onto the films as observed when using a spacer instead of BSA (Table IV, Expts. 1 and 2). In addition, about the same increase of the hydrophilicity was found and the results therefore indicate that immobilization of BSA or of a spacer influenced the immobilization of ALP in a similar way. It is also clear from Table IV that insertion of a spacer between the support and BSA resulted only in a slight increase of the activity (Expt. 3). However, separation of BSA and ALP using a spacer markedly increased the enzymatic activity of the films (Expt. 4), whereas about the same effect was found using another spacer (Expt. 5).

Although from the results a specific effect of BSA cannot be concluded, coupling of ALP with BSA seems to be negatively influenced by steric interaction, because when using a spacer a considerable increase of the enzymatic activity was observed. An increase of active enzyme bound onto the support by insertion of BSA as well as of spacers between the support and the enzyme was also observed by Da Silva et al. for the immobilization of glucose oxidase onto nylon membranes. ${ }^{28}$

\section{Properties of the Immobilized ALP}

The characteristics of the immobilized enzyme by direct fixation or through spacers on the grafted LDPE films were studied to obtain information on changes of enzymatic properties caused by the immobilization. The $\mathrm{pH}$ profiles, the Michaelis-Menten constants, thermal stability, reusability, and storage stability of the films with immobilized ALP were determined.

\section{pH Profiles}

The effect of the $\mathrm{pH}$ of the reaction medium on the activity of the immobilized ALP were investigated and the results are shown in Figure 2. The optimal $\mathrm{pH}$ value for the native and the immobilized ALP appears to be the same $(\approx 9.4)$, with different spacers inserted between the enzyme and the films. Values for the optimal $\mathrm{pH}$ that were about the same for the immobilized enzyme and the native enzyme were also found when ALP was immobilized onto other polymeric supports. ${ }^{3,4}$

\section{Kinetic Constants}

Typical Lineweaver-Burk plots for the determination of the Michaelis-Menten constants for the native and the immobilized ALP are shown in Figure 3 and 4, respectively, and the apparent $K_{m}$ values for the immobilized ALP are given in Table IV. The native ALP showed a $K_{m}$ value of $0.059 \mathrm{mmol} / \mathrm{L}$ (Fig. 3). For immobilized ALP, in most cases, a higher $K_{m}$ value was found. The apparent $K_{m}$ value of the immobilized ALP without a spacer (GVV-E, $0.091 \mathrm{mmol} / \mathrm{L})$ was higher than the $K_{m}$ of the immobilized ALP with spacer (GVV-DAH-E, 0.033 $\mathrm{mmol} / \mathrm{L}$ ) and also than the $K_{m}$ of native ALP, which may be due to diffusion limitation of the substrate to the matrix. ${ }^{1,4,28}$ The higher $K_{m}$ for the immobilized ALP onto the albuminated supports (Expts. $2-5$ in Table IV) than the $K_{m}$ when using a spacer (DAH) might be attributed to the negative charge of BSA at $\mathrm{pH} 9.4$, leading to a repulsion between the negatively charged substrate ( $p$ NPP) and the immobilized enzyme, ${ }^{1}$ as was found for immobilized ALP onto PVCA beads blocked with glycine. ${ }^{37}$

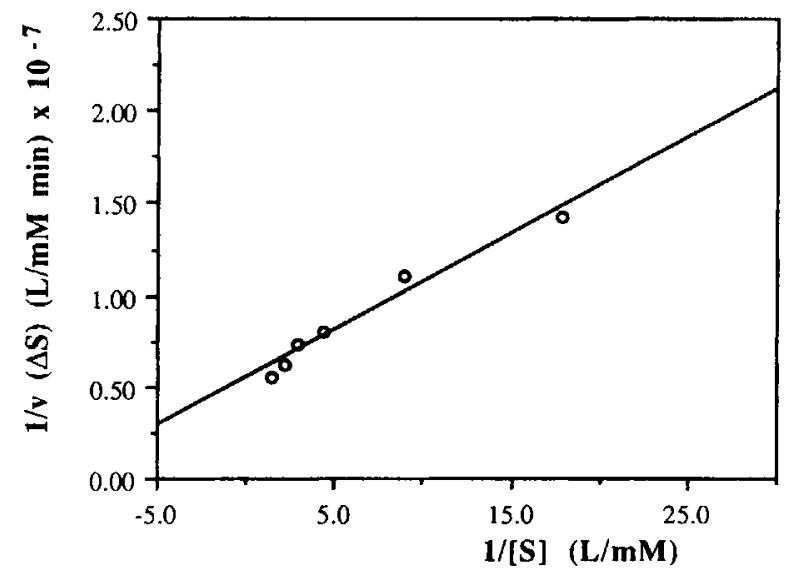

Figure 4 Lineweaver-Burk plot for immobilized ALP (sample GVV-A-DAH-E). 


\section{Thermal Stability}

The thermal stability of native ALP and of ALP immobilized through a spacer to the albuminated surface ( sample GVV-A-DAH-E) was measured by incubation in $0.05 \mathrm{M}$ glycine buffer, $\mathrm{pH} 9$ at $37^{\circ} \mathrm{C}$. From the curves shown in Figure 5 for the thermoinactivation of native and immobilized ALP, the following rate constants could be calculated: $k_{i}$ $=1.54 \times 10^{-2}\left(\mathrm{~min}^{-1}\right)$ for native ALP and $k_{i}=0.85$ $\times 10^{-2}\left(\mathrm{~min}^{-1}\right)$ for the immobilized ALP. It is clear that the immobilized ALP manifests an increase in thermal stability when compared to that of the native one, possibly due to the covalent binding of ALP onto the support, leading to a reduction in mobility. ${ }^{42}$

\section{Reusability}

Reusability of the immobilized ALP (sample GVVA-DAH-E) was also investigated, and the activity of the immobilized ALP after repeated use is shown in Figure 6. After having used it nine times, the residual activity of the immobilized ALP was about $80 \%$, which indicates that the immobilized alkaline phosphatase is relatively stable for repeated use without severe loss of activity.

\section{Storage Stability}

The immobilized ALP (sample GVV-A-DAH-E) was stored at $4^{\circ} \mathrm{C}$ in $0.05 \mathrm{M}$ Tris- $\mathrm{HCl}$ buffer at $\mathrm{pH}$ 8 for 1 month and the residual activity was found to be about $65 \%$.

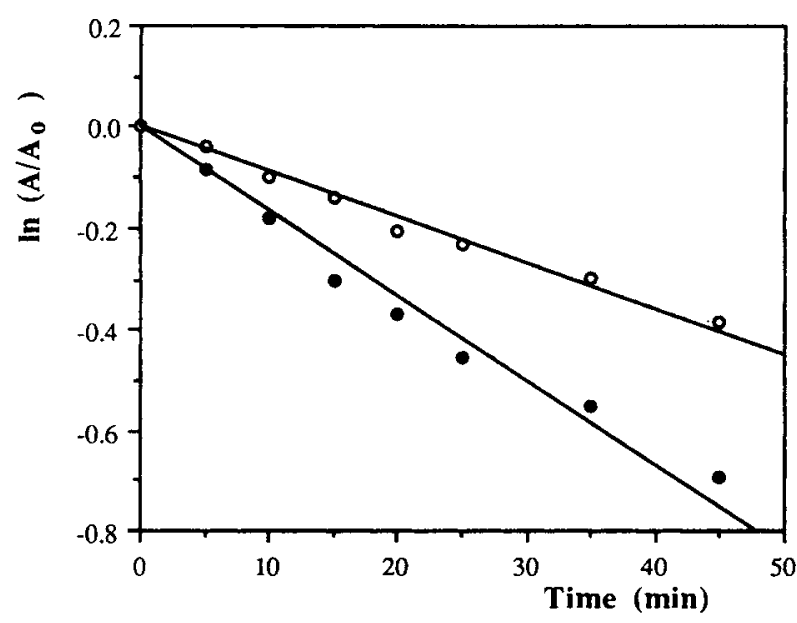

Figure 5 Activity change of ALP (๑) and of immobilized ALP (O) by heat treatment at $37^{\circ} \mathrm{C}$ and $\mathrm{pH} 9$. ( sample GVV-A-DAH-E).

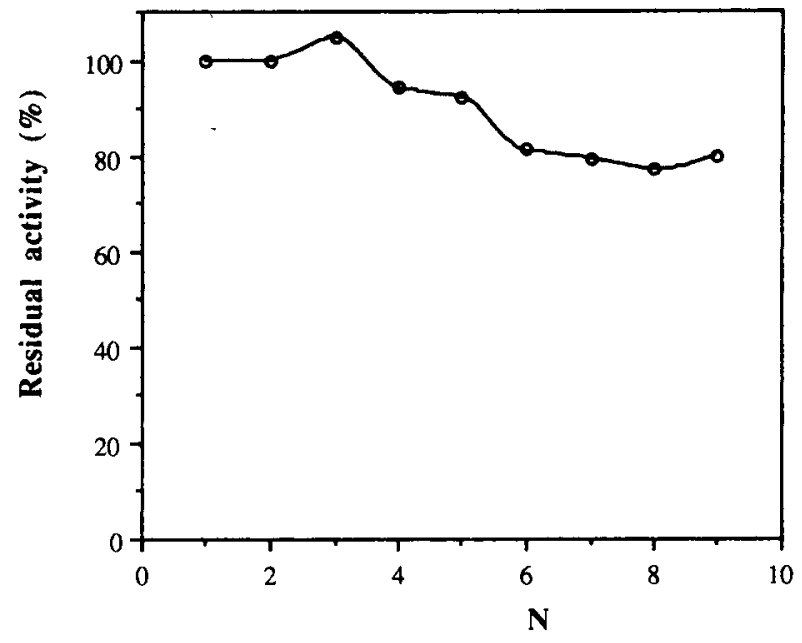

Figure 6 Effect of repeated use (N) on the activity of immobilized ALP (sample GVV-A-DAH-E).

\section{CONCLUSIONS}

As a result of this study of the immobilization of alkaline phosphatase onto VCA-VIMA-grafted LDPE films, we can conclude that the films might be used as a matrix for the coupling of enzymes. Coupling to "spacer arms" or to a bovine serum albuminated layer increases the amount of active ALP bound onto the film because of a more "comfortable" microenvironment for the enzyme. The highest surface concentration of active ALP coupled onto the films was achieved when inserting a spacer (diaminohexane, DAH) between the albuminated surface and the enzyme before coupling. Compared to native ALP, some physicochemical properties of ALP could be improved by covalent immobilization.

\section{REFERENCES}

1. I. Chibata, Immobilized Enzymes, Research and Development, Halsted, New York, 1978.

2. K. Takemoto, Y. Inaki, and R. M. Ottenbrite, Functional Monomers and Polymers, Marcel Dekker, New York, 1987.

3. O. Zaborsky, Immobilized Enzymes, CRC Press, Cleveland, OH, 1973.

4. L. Grasset, D. Cordier, R. Couturier, and A. Ville, Biotechnol. Bioeng., 25, 1423 (1983).

5. L. D'Angiuro, P. Cremonesi, R. Cantafi, G. Mazzola, and G. Vecchio, Angew. Makromol. Chem., 91, 161 (1980).

6. S. Dumitriu, V. Bulacovschi, L. Baston, and Cr. Simionescu, Acta Polym., 35, 536 (1984). 
7. W. Brummer, N. Hennrich, M. Klockow, H. Lang, and H. D. Orth, Eur. J. Biochem., 25, 129 (1972).

8. I. Zemanova, J. Turkova, M. Capka, L. A. Nakhapetyan, F. Svec, and J. Kalal, Enzyme Microb. Technol., 3, 229 (1981).

9. A. Rosevear, J. F. Kennedy, and J. M. S. Cabral, in Immobilized Enzymes and Cells, IOP Pub. Ltd., Adam Hilger, Bristol and Philadelphia, 1987.

10. A. S. Hoffman, G. Schmer, C. Harris, and W. G. Kraft, Trans. Am. Soc. Artif. Intern. Organs, 18, 10 (1972).

11. M. J. Liddy, J. L. Garnett, and R. S. Kenyon, J. Polym. Sci. Polym. Symp., 49, 109 (1975).

12. D. Muller-Schulte and F. A. Horter, Polym. Bull., 7, 395 (1982).

13. F. I. Abdel-Hay, C. G. Beddows, and J. T. Guthrie, Makromol. Chem., 182, 717 (1981).

14. C. G. Beddows, M. H. Gil, and J. T. Guthrie, Biotechnol. Bioeng., 28, 51 (1986).

15. K. Raghunath, K. P. Rao, and K. T. Joseph, Biotechnol. Bioeng., 26, 104 (1984).

16. A. S. Hoffman, W. G. Gombotz, S. Uenoyama, L. C. Dong, and G. Schmer, Radiat. Phys. Chem., 27, 265 (1986).

17. G. H. Hsiue, C. C. Wang, C. Y. Chen, and C. J. Chang, Angew. Makromol. Chem., 179, 149 (1990).

18. S. A. Barker, S. H. Doss, C. J. Gray, J. F. Kennedy, M. Stacey, and T. H. Yeo, Carbohydr. Res., 20, 1 (1971).

19. N. W. H. Cheethan and G. N. Richards, Carbohydr. Res., 30, 99 (1973).

20. S. A. Barker, H. C. Tun, S. H. Doss, C. J. Gray, and J. F. Kennedy, Carbohydr. Res., 17, 471 (1971).

21. H. Huemer and R. Schmidtberger, Ger. Offen. 2,552,510; CA87: 97805 (1977).

22. O. Mauz and K. Sauber, Ann. N.Y. Acad. Sci., 434, 251 (1984).

23. O. Mauz, K. Sauber, and S. Noetzel, Ger. Offen, DE 3,243,591; CA101: 172321 (1982).

24. G. H. Chen, L. van der Does, and A. Bantjes, J. Appl. Polym. Sci., to appear.

25. T. Hayashi and Y. Ikada, Biotechnol. Bioeng., 36, 593 (1990).
26. S. Emi, Y. Murase, T. Hayashi, and A. Nakajima, J. Appl. Polym. Sci., 41, 2753 (1990).

27. M. A. Da Silva and M. H. Gil, Analytical Uses of Immobilized Biological Compounds for Detection, Medical and Industrial Uses, NATO ASI Series, C. Guilbault and M. Mascini, Eds., Reidel, Dordrecht, 1988, p. 177.

28. M. A. Da Silva, M. H. Gil, J. S. Redinha, A. M. O. Brett, and J. L. C. Pereira, J. Polym. Sci. Polym. Chem., 29, 275 (1991).

29. A. Safranj, D. Kiaei, and A. S. Hoffman, Biotechnol. Prog., 7, 173 (1991).

30. J. X. Huang, G. H. Chen, E. J. Tijsma, L. van der Does, and A. Bantjes, Chin. J. Polym. Sci., 8, 197 (1990).

31. R. N. King, J. D. Andrade, and S. M. Ma, J. Coll. Interf. Sci., 103, 62 (1985).

32. G. H. Hsiue, Z. S. Chou, N. Yu, and K. P. Hsiung, J. Appl. Polym. Sci., 34, 319 (1987).

33. O. A. Bessey, O. H. Lowry, and M. J. Brock, J. Biol. Chem., 164, 321 (1946).

34. H. D. Conlon and D. R. Walt, J. Chem. Ed., 63, 368 (1986).

35. R. G. Degtyar and M. F. Gulyi, Biokhim. Zh., 53, 42 (1981).

36. F. I. Abdel-Hay, C. G. Beddows, M. H. Gil, and J. T. Guthrie, J. Polym. Sci. Polym. Chem. Ed., 21, 2463 (1983).

37. G. H. Chen, L. van der Does, and A. Bantjes, J. Appl. Polym. Sci., submitted.

38. V. G. Jayakumari and V. N. R. Pillai, J. Appl. Polym. Sci., 42, 583 (1991).

39. V. D. Nemirovsky and S. S. Skorokhodov, J. Polym. Sci. Part C, 16, 1471 (1967).

40. H. Kitano, M. Hasegawa, T. Kaku, and N. Ise, J. Appl. Polym. Sci., 39, 241 (1990).

41. S. Dumitriu, M. Popa, V. Artenie, and F. Dan, Biotechnol. Bioeng., 34, 283 (1989).

42. R. Ulbrich, A. Schellenberger, and W. Damerau, Biotechnol. Bioeng., 28, 511 (1986).

Received October 18, 1991

Accepted February 21, 1992 